\title{
Effects of Perilla (Perilla frutescens L.) Meal as Partial Replacement for Soybean Meal on Metabolizability, Performance, and Carcass Characteristics of Broilers
}

\author{
Napatsorn MONTHA ${ }^{1}$, Winai YOTHINSIRIKUL ${ }^{2}$, Kittipong TIPPAYA ${ }^{2}$, \\ Michael KREUZER ${ }^{3}$ and Sanchai JATURASITHA, ${ }^{1,4, *}$ \\ ${ }^{1}$ Department of Animal and Aquatic Sciences, Faculty of Agriculture, Chiang Mai University, \\ Chiang Mai 50200, Thailand \\ ${ }^{2}$ Faculty of Animal Science and Technology, Maejo University, Chiang Mai 50290, Thailand \\ ${ }^{3}$ ETH Zurich, Institute of Agricultural Sciences, Zurich, Switzerland \\ ${ }^{4}$ Science and Technology Research Institute, Chiang Mai University, Chiang Mai, 50200 Thailand
}

('Corresponding author's e-mail: ja.sanchai@gmail.com)

Received: 23 March 2020, Revised: 7 September 2020, Accepted: 31 October 2020

\begin{abstract}
There is an ongoing search for novel protein sources suitable to replace soybean meal. The present study aimed to investigate the utility of cold-pressed perilla seed meal for broiler diets. Perilla meal was included at dietary levels of 0,4 , and $8 \%$. In the first experiment, apparent digestibility and metabolisability of nutrients were performed with 24 Cobb 500 broilers. In the second experiment, growth performance and carcass quality were investigated in $120 \mathrm{Cobb} 500$ broilers. The inclusion of perilla meal into the diet in an iso-nitrogenous way increased feed intake and metabolisability of nitrogen but decreased the digestibility of fat and fiber as well as the metabolisability of energy. The highest proportion of perilla meal enhanced the growth performance. Carcass weight and dressing percentage did not differ among groups. Proportions of total retail cuts and, among them, breast meat and thighs, were elevated by using perilla meal, especially at a level of $8 \%$. The proportion of abdominal fat declined with increasing levels of perilla meal. In conclusion, perilla meal turned out to be a valuable protein source in broiler nutrition. It also showed that part of the soybean meal could be replaced without risking adverse effects on growth performance and carcass quality.
\end{abstract}

Keywords: Perilla frutescens, Protein, Poultry, Digestion, Breast meat

\section{Introduction}

The costs associated with broiler meat production are dominated by feed, accounting for more than $70 \%$ [1], which greatly limits profitability. Thus, there is an ongoing search for less expensive alternatives to common feed ingredients. An additional goal was to reduce the dependency on soybean meal as a source of protein. Several agri-food industry by-products have been tested as alternative protein sources in monogastric animals, such as camelina (false flax or Camelina sativa) [2] and palm kernel meal [3].

Another potential yet uncommon feed supplement in animal nutrition is perilla (Perilla frutescens L.). The perilla plant, cultivated in Asia, contains seeds that are well-known for their high lipid and protein contents. The seeds contain about $40 \%$ oil [4], with lipids richer in $\alpha$-linoleic acid, representing the n-3 fatty acids, than that of linseed oil [5]. The extracted oil may be used for medicinal purposes to lower blood lipid levels, reduce the risk of thrombosis, prevent Alzheimer's disease, and decrease the risk of cardiovascular disease and sudden death from ventricular fibrillation and tachycardia [6]. Perilla seeds 
http://wjst.wu.ac.th

were also tested as feed for laying hens [7] and sheep [5]. The oil extraction in perilla meal enriches the protein content to about one-third of total protein, half of which are essential amino acids [8]. Unlike soybean seeds, perilla seeds have no trypsin-inhibiting activity [4]; thus, they do not require additional steam treatment to valorize it as an animal feed.

Until now, few studies have been conducted on perilla meal as a protein supplement for monogastric animals. Slow-growing native Korean chickens were fed diets containing $10 \%$ perilla meal [9], wherein the authors found no significant effects on growth performance or breast meat proportion of body weight. However, the $\alpha$-linolenic acid proportion of the breast meat lipids increased threefold. This indicates that the residual oil remaining in the perilla meal could favorably modify the muscle lipids.

Another study compared various plant protein sources, including perilla meal, with respect to their effects on growth performance and digestibility in finishing pigs [10]. In that study, feed efficiency was higher with perilla meal compared to that of soybean meal. However, the ideal digestibility coefficients for protein and essential amino acid were lower with perilla meal than with soybean meal. Energy and ether extract digestibility were higher in rabbits fed with $10 \%$ diet supplemented perilla meal than those with either $5 \%$ perilla meal or soybean meal as a protein source [11]. In further research, pigs, which we fed with a diet containing $10 \%$ perilla meal, required the least amount of time to reach a target slaughter weight $(110 \mathrm{~kg})$ and had the highest average daily gains (ADG) compared with pigs fed diets with 0,15 , and $20 \%$ perilla meal [12]. The $15 \%$ inclusion group showed medium backfat thickness, whereas the 20 $\%$ inclusion group produced the thinnest back fat on top of the shoulders. There was also a correlation between the fatty acids of perilla meal and proportions of perirenal fat, backfat, intermuscular fat, and intramuscular fat [12].

As perilla meal utility for fast-growing broilers has not yet been investigated, the present study aimed to test if perilla meal could be used without impairing growth performance. The hypothesis tested was that a limited proportion of soybean meal could be replaced by perilla meal in broiler diets without any adverse effects on most if not all performance characteristics, metabolizability, and carcass quality. We further surmised that there exists a dose-response relationship between dietary perilla meal proportions and the resulting traits.

\section{Materials and methods}

\section{Animal care}

The experimental protocol herein was approved by the Ethics Committee on Animal Experimentation of Maejo University, Chiang Mai, Thailand (no. MACUC016A/2559).

\section{Experimental diets}

Two sets of 3 diet types, containing 0,4 , and $8 \%$ lipid-extracted perilla seed meal, were mixed for both the starter and finisher phases (Table 1). Additionally, proportions of soybean meal were reduced in an iso-nitrogenous manner by about 2.5 and $5.5 \%$, respectively. Similarly, the proportion of maize lowered and the proportion of palm oil was increased to compensate for the high fiber contents (likely from the hulls of the seeds) and the concomitantly limited energy contents of the perilla meal. Each diet was calculated to contain 12.4 and $13.2 \mathrm{MJ}$ metabolizable energy (ME)/kg for starter and finisher period, respectively. The process followed the existing recommendations for protein and energy in broiler diets [13]. The perilla meal batch was a by-product from a cold extraction of perilla oil, delivered in large sheets after drying [14], and ground into powder. The broilers were given ad libitum access to the diets offered in mealy form.

\section{Experiment 1}

Twenty-four broilers (Cobb 500) with 1 day of age of mixed gender were obtained from a Thai commercial company. The birds had been reared following the guidelines of the Office International des Epizooties [15]. The broilers were reared together from 1 day of age until being 27 days old. The broilers were assigned to the 3 dietary treatments following a randomized design at an age of 28 days. Each treatment included 8 replications ( 1 broiler/replication). The broilers were housed in individual cages with 
http://wjst.wu.ac.th

a floor size of $30 \times 40 \mathrm{~cm}^{2}$ and a mesh size of $2.5 \times 2.5 \mathrm{~cm}^{2}$. A board for the collection of excreta was mounted beneath the cage floors, and the excreta were collected four times per day. The experiment lasted for 14 days at an average (summer) room temperature with a humidity of $35{ }^{\circ} \mathrm{C}$ and $58 \%$, respectively. The initial 7 days served as a period of adaptation to the diets ( 28 - 34 days of age).

After that, at the age of 35 days, the first meal was mixed with $0.3 \%$ ferric oxide to be a maker for starting excreta collection. Then, at the age of 41 days, the broiler's last meal was mixed with $0.3 \%$ ferric oxide again to be a marker for stopping excreta collected. The excreta collection period was determined by the occurrence and absence of dark red colored excreta, respectively. Feathers and feed residues were removed from the excreta collection. Then the excreta samples were weighed, homogenized, and frozen at $-20{ }^{\circ} \mathrm{C}$. After thawing, the composited excreta samples were homogenized and dried in a forcedventilation oven at $60{ }^{\circ} \mathrm{C}$ for 72 hours, and later ground in a micro-mill. Diets and excreta were analyzed for dry matter (DM), total ash (with organic matter being DM minus total ash), ether extract, and crude fiber [16]. Nitrogen contents were analyzed via the Kjeldahl method [16], and gross energy was determined using a bomb calorimeter (model 1281, PARR Instruments, USA). The analyses of Ca and P was done through spectrophotometry [16]. The dietary lipids' fatty acid profile was determined by gas chromatographic analysis using a GC121 14B (Shimadzu, Kyoto, Japan) equipped with a $0.25 \mathrm{~mm} \times 30$ $\mathrm{m} \times 0.25 \mu \mathrm{m}$ wall-coated fused wax capillary column and helium as a carrier gas. Oven temperature programming included an increase from 50 to $220{ }^{\circ} \mathrm{C}$ at $10{ }^{\circ} \mathrm{C} / \mathrm{min}$, ramped for $35 \mathrm{~min}$; and an increase from 200 to $230{ }^{\circ} \mathrm{C}$ at $5{ }^{\circ} \mathrm{C} / \mathrm{min}$, ramped for $20 \mathrm{~min}$ at $230{ }^{\circ} \mathrm{C}$. Injector and detector temperatures were $250{ }^{\circ} \mathrm{C}$. Chromatograms were processed using a Millennium 2010 Chromatography Manager (Millipore Corp., Milford, Massachusetts, USA).

\section{Experiment 2}

One-hundred and twenty 1-day old broilers (Cobb 500) of mixed gender were divided into 3 groups following a complete randomized design. Each treatment was represented by four pens $\left(2 \times 1.5 \mathrm{~m}^{2}\right)$ containing ten birds each. The floors were covered with rice husks. Feed containers hanging above the floor were built to avoid feed losses, and both feed and water were refilled three times a day. Fattening lasted for 6 weeks. The average room temperature was $28^{\circ} \mathrm{C}$, and the air humidity was $58 \%$. Feed intake was determined every week per pen. The birds were weighed individually on Day 1 , and then once a week until slaughter. The birds were transported to the slaughterhouse, allowed to rest for $2 \mathrm{~h}$, and then slaughtered and dressed according to commercial practices. Accordingly, the head, internal organs, and non-carcass parts were removed from the carcass. Hot carcass weights were recorded at $40 \mathrm{~min}$ p.m., and later carcasses were chilled at $3{ }^{\circ} \mathrm{C}$ for $24 \mathrm{~h}$ and weighed again. Dressing percentages were calculated as the proportion of cold carcass weight and body weight (BW) at slaughter. Following Thai practices [17], the carcasses were dissected into four retail cuts: breast (outer part of the M. pectoralis major); tenderloin (inner part of the M. pectoralis major), thigh, and drumstick; and the weights of each individual cut were recorded.

\section{Statistical analysis}

Data were subjected to analysis of variance using SAS version 6.12 (SAS Institute Inc., Cary, NC, USA). The pens or individual birds (where applicable) were considered experimental units, and the diets were considered a fixed effect. Duncan's multiple range test was used for multiple comparisons among means, in which the statistical significance was declared as $\mathrm{p}<0.05$.

\section{Results and discussion}

The perilla meal batch was rich in protein and fiber, and ether extract (Table 1). The residual oil consisted of $50 \% \alpha$-linolenic acid. The goal of creating iso-nitrogenous diets within the starter and finisher diets was achieved. The diets containing 4 and $8 \%$ perilla meal presented higher ether extract and gross energy contents due to both the residual perilla seed oil and the supplementary palm oil. In addition, the proportions of polyunsaturated fatty acids increased, and those of the mono-unsaturated fatty acids decreased. 
http://wjst.wu.ac.th

Table 1 Ingredients and nutrient compositions of the experimental diets.

\begin{tabular}{|c|c|c|c|c|c|c|c|}
\hline \multirow{2}{*}{ Perilla meal (\%) } & \multirow{2}{*}{100} & \multicolumn{3}{|c|}{ Starter diet ( 0 - 21 days of age) } & \multicolumn{3}{|c|}{ Finisher diet ( 22 - 42 days of age) } \\
\hline & & $\mathbf{0}$ & 4 & 8 & $\mathbf{0}$ & 4 & 8 \\
\hline \multicolumn{8}{|l|}{ Ingredients $(\%)$} \\
\hline Perilla meal & 100 & - & 4.00 & 8.00 & - & 4.00 & 8.00 \\
\hline Soybean meal & - & 36.9 & 34.3 & 31.5 & 32.1 & 29.2 & 26.7 \\
\hline Maize & - & 39.4 & 38.2 & 36.3 & 46.8 & 44.9 & 43.1 \\
\hline Palm oil & - & 5.50 & 5.70 & 6.50 & 4.20 & 4.95 & 5.40 \\
\hline Rice bran & - & 15.0 & 15.0 & 15.0 & 15.0 & 15.0 & 15.0 \\
\hline Oyster shell meal & - & 1.25 & 1.20 & 1.20 & 0.30 & 0.30 & 0.30 \\
\hline Bone meal & - & 1.15 & 0.80 & 0.70 & 0.80 & 0.90 & 0.75 \\
\hline $\mathrm{NaCl}$ & - & 0.35 & 0.35 & 0.35 & 0.35 & 0.35 & 0.35 \\
\hline 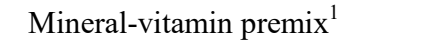 & - & 0.25 & 0.25 & 0.25 & 0.25 & 0.25 & 0.25 \\
\hline L-Lysine $\mathrm{HCl}$ & - & 0.20 & 0.20 & 0.20 & 0.20 & 0.20 & 0.20 \\
\hline \multicolumn{8}{|c|}{ Analyzed composition ( $\%$ of air-dry matter) } \\
\hline Dry matter & 92.8 & 89.8 & 89.0 & 88.0 & 89.6 & 89.0 & 88.5 \\
\hline Organic matter & 95.8 & 90.4 & 90.1 & 89.9 & 90.8 & 90.3 & 90.1 \\
\hline Crude protein & 33.2 & 23.0 & 23.0 & 23.0 & 20.5 & 20.6 & 20.6 \\
\hline Ether extract & 12.1 & 9.20 & 10.4 & 11.3 & 7.61 & 8.32 & 10.6 \\
\hline Crude fiber & 36.0 & 3.11 & 3.91 & 4.20 & 3.01 & 3.69 & 4.19 \\
\hline $\mathrm{Ca}$ & 0.68 & 0.88 & 0.89 & 0.81 & 0.91 & 0.84 & 0.84 \\
\hline $\mathrm{P}$ & 0.85 & 0.57 & 0.59 & 0.53 & 0.71 & 0.66 & 0.62 \\
\hline Lysine & 1.26 & 1.39 & 1.36 & 1.33 & 1.27 & 1.24 & 1.22 \\
\hline Gross energy (MJ/kg) & 20.4 & 18.3 & 18.9 & 19.5 & 18.7 & 19.2 & 19.8 \\
\hline Metabolizable energy (MJ/kg) & - & 12.6 & 12.4 & 12.3 & 13.4 & 13.3 & 13.2 \\
\hline \multicolumn{8}{|c|}{ Analyzed fatty acid (FA) profile (\% of total FA) } \\
\hline $\mathrm{C} 14: 0$ & 0.42 & 13.1 & 15.4 & 12.1 & 12.6 & 15.9 & 13.7 \\
\hline $\mathrm{C} 16: 0$ & 14.0 & 31.0 & 39.1 & 31.7 & 30.3 & 35.4 & 31.1 \\
\hline C18:0 & 4.26 & 2.01 & 2.87 & 5.24 & 2.13 & 2.32 & 4.38 \\
\hline C18:1 n-9 & 7.64 & 38.8 & 23.0 & 16.4 & 39.9 & 27.8 & 18.4 \\
\hline $\mathrm{C} 18: 2 \mathrm{n}-6$ & 25.8 & 14.2 & 17.4 & 27.2 & 14.4 & 16.8 & 26.0 \\
\hline C18:3 n-3 & 47.9 & 0.79 & 2.76 & 7.41 & 0.48 & 1.87 & 5.47 \\
\hline Saturated FA & 18.8 & 46.1 & 57.4 & 49.1 & 45.0 & 53.6 & 50.2 \\
\hline Mono-unsaturated FA & 7.64 & 38.9 & 23.0 & 16.4 & 39.9 & 27.8 & 18.4 \\
\hline Poly-unsaturated FA & 73.6 & 15.0 & 19.5 & 34.5 & 15.1 & 18.6 & 31.4 \\
\hline n-6:n-3 fatty acid ratio & 0.53 & 18.3 & 6.12 & 3.78 & 29.4 & 8.76 & 4.77 \\
\hline
\end{tabular}

${ }^{1}$ Composed, per kg, of Co, 0.08 g; Cu, 1.6 g; Fe, 16 g; I, 0.17 g; Mg, 12.2 g; Zn, 8 g; Se, 0.06; vitamin A, 400’000 $\mathrm{IU}$; vitamin $\mathrm{B}_{1}, 200 \mathrm{mg}$, vitamin $\mathrm{B}_{2}, 300 \mathrm{mg}$; vitamin $\mathrm{B}_{6}, 300 \mathrm{mg}$; niacin, $1500 \mathrm{mg}$; calcium pantothenate, $500 \mathrm{mg}$; folic acid, $5.5 \mathrm{mg}$; vitamin $\mathrm{B}_{12}$, vitamin $\mathrm{D}_{3}, 100$ ’000 IU; vitamin $\mathrm{E}, 750 \mathrm{mg}$, vitamin $\mathrm{K}_{3}, 75 \mathrm{mg}, 1 \mathrm{mg}$; biotin, $5 \mathrm{mg}$.

\section{Experiment 1}

The 35 to 41 days old broilers consumed nearly $1 \mathrm{~kg}$ of feed per week (Table 2). Feed intake increased with the inclusion of perilla meal $(\mathrm{p}<0.05)$, independent of its level. Broilers fed with $8 \%$ perilla meal excreted higher amounts of DM than those which did not receive perilla meal. The group fed $4 \%$ perilla meal was intermediate $(\mathrm{p}<0.05)$. The apparent digestibility values of ether extract and crude fiber decreased with increasing proportions of perilla meal in the diets $(\mathrm{p}<0.05)$, although not significantly between the 0 and $4 \%$ perilla meal inclusions with crude fiber digestibility. Additionally, dietary energy's apparent metabolizability declined $(p<0.05)$ with increasing perilla meal levels. The measured ME content of the diets did not change with any of the perilla meal inclusion. The apparent

4 of $11 \quad$ Walailak J Sci \& Tech 2021; 18(4): 9692 
http://wjst.wu.ac.th

nitrogen metabolizability increased by 5.5 and $11.3 \%(\mathrm{p}<0.05)$ within the 4 and $8 \%$ perilla meal diets, respectively, compared to the control ( $0 \%$ perilla meal).

Table 2 Effects of perilla meal on intake, excreta amount, apparent digestibility, and metabolizability; as well as the contents of metabolizable energy (ME) measured in Week 5 of Experiment 1 (means $\pm \mathrm{SD}$; $\mathrm{n}$ $=8$ per diet).

\begin{tabular}{|c|c|c|c|c|c|}
\hline \multirow[b]{2}{*}{ Item } & \multicolumn{5}{|c|}{ Perilla meal (\% of diet) } \\
\hline & $\mathbf{0}$ & 4 & 8 & SEM $^{1}$ & P-value \\
\hline Dry matter intake (g/week) & $899^{b} \pm 42$ & $986^{\mathrm{a}} \pm 36$ & $940^{a} \pm 51$ & 67.1 & 0.041 \\
\hline Dry matter excretion (g/week) & $98^{\mathrm{b}} \pm 15$ & $103^{\mathrm{ab}} \pm 13$ & $113^{\mathrm{a}} \pm 7.0$ & 12.01 & 0.044 \\
\hline $\begin{array}{l}\text { Apparent digestibility }(\%) \\
\text { Ether extract } \\
\text { Crude fiber }\end{array}$ & $\begin{array}{l}87.8^{\mathrm{a}} \pm 2.4 \\
34.1^{\mathrm{a}} \pm 0.1\end{array}$ & $\begin{array}{l}84.0^{\mathrm{b}} \pm 2.4 \\
32.2^{\mathrm{a}} \pm 0.1\end{array}$ & $\begin{array}{l}80.0^{\mathrm{c}} \pm 1.7 \\
29.4^{\mathrm{b}} \pm 0.2\end{array}$ & $\begin{array}{l}2.18 \\
2.34\end{array}$ & $\begin{array}{l}<0.001 \\
0.031\end{array}$ \\
\hline $\begin{array}{l}\text { Apparent metabolizability (\%) } \\
\text { Energy }^{2} \\
\text { Nitrogen }\end{array}$ & $\begin{array}{l}76.1^{\mathrm{a}} \pm 1.0 \\
56.5^{\mathrm{c}} \pm 2.7\end{array}$ & $\begin{array}{l}69.3^{b} \pm 1.0 \\
62.1^{b} \pm 4.4\end{array}$ & $\begin{array}{l}66.7^{\mathrm{c}} \pm 1.3 \\
67.8^{\mathrm{a}} \pm 3.6\end{array}$ & $\begin{array}{l}5.36 \\
3.62\end{array}$ & $\begin{array}{l}0.023 \\
0.008\end{array}$ \\
\hline $\mathrm{ME}(\mathrm{MJ} / \mathrm{kg} \text { dry matter })^{2}$ & $13.4 \pm 0.2$ & $13.3 \pm 0.4$ & $13.2 \pm 0.3$ & 0.49 & 0.135 \\
\hline
\end{tabular}

${ }^{a-c}$ Means in the same row with different superscripts differ significantly $(p<0.05)$.

${ }^{1}$ SEM: Standard error of the mean.

${ }^{2}$ This refers to the finisher diet.

\section{Experiment 2}

All birds successfully completed the second experiment. Similar to the results found in Experiment 1 , DM intake was higher $(\mathrm{p}<0.05)$ with $8 \%$ perilla meal than without perilla meal in the finishing phase (weeks 4 - 6) of growth (Table 3).

However, unlike to the first experiment, intake did not differ between the 0 and $4 \%$ perilla meal inclusions, and no effects of perilla meal on DM intake in the starter phase were observed. Starting with similar body weights, total gains and ADG were higher $(\mathrm{p}<0.05)$ with $8 \%$ perilla meal than that of the 0 and $4 \%$ inclusions. With regards to weekly development, the ADG increased until week 5 of the experiment and decreased to some extent in week 6, throughout each of the 3 treatments (Figure 1). Individually (Figure 2) and across all 6 weeks (Table 3), feed conversion ratios did not differ among treatments and varied from week to week. 


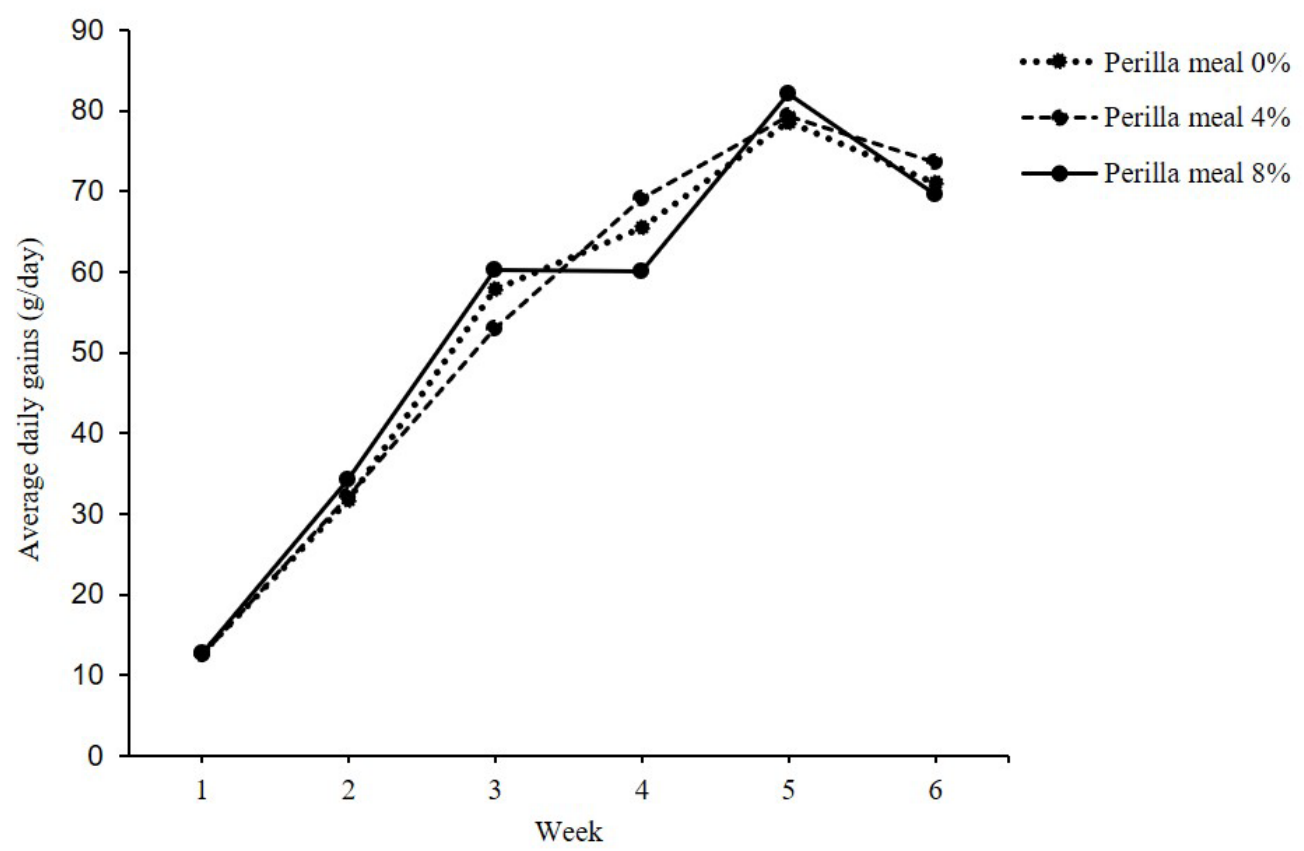

Figure 1 Effect of perilla meal supplementation on average daily gains.

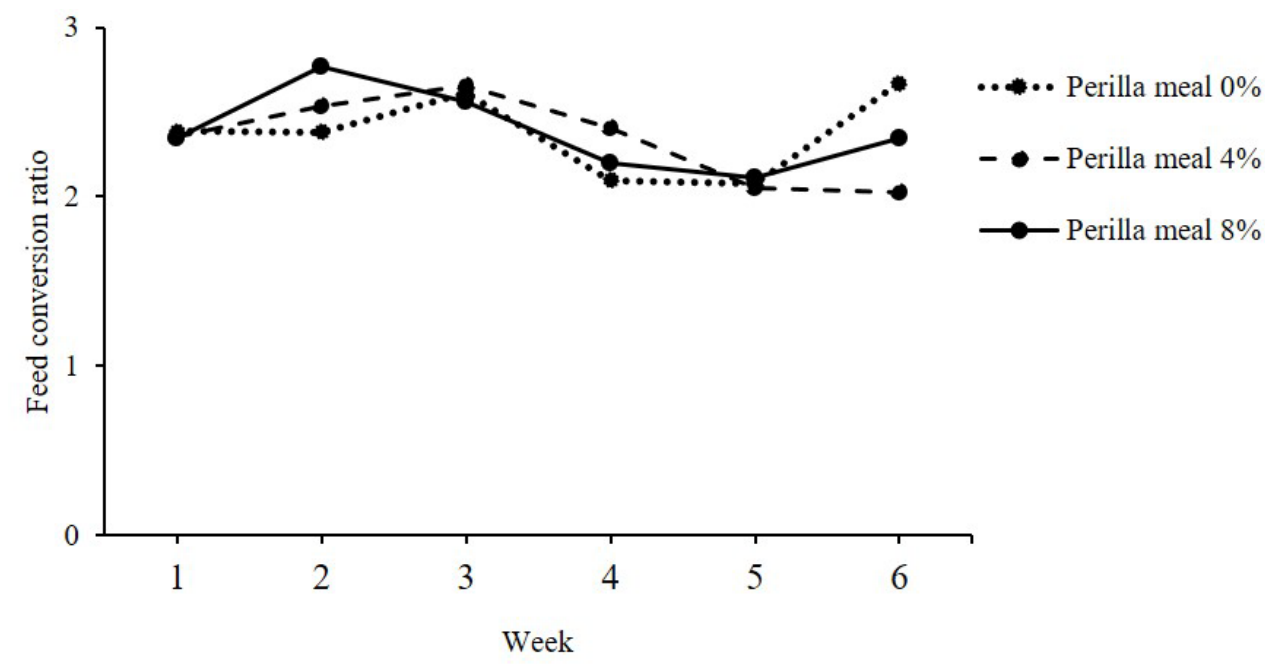

Figure 2 Effect of perilla meal supplementation on feed conversion ratio.

The dietary treatments significantly affected carcass weight and dressing percentage, which ranged between 73 and $75 \%$ (Table 3). Overall, the highest perilla meal level resulted in the highest carcass weight proportions in each of the retail cuts investigated $(p<0.05)$, whereas the difference between birds receiving diets with 0 and $4 \%$ perilla meal was not significant. Similar differences were found in thigh proportions, whereas breast meat proportions increased with any perilla meal addition at a magnitude of 2 $\%(\mathrm{p}<0.05)$. Tenderloin proportions were highest within the $4 \%$ perilla meal inclusion $(\mathrm{p}<0.05)$. The 
http://wjst.wu.ac.th

overall proportion of abdominal fat of total final BW gradually decreased, with decreases accounting for 0.30 and $0.72 \%$ within the 4 and $8 \%$ perilla meal inclusions, respectively.

Table 3 Effects of perilla meal on the growth performance and carcass properties measured in Experiment 2 (means $\pm \mathrm{SD}$ ).

\begin{tabular}{|c|c|c|c|c|c|}
\hline \multirow{2}{*}{ Item } & \multicolumn{3}{|c|}{ Perilla meal (\% of diet) } & \multirow{2}{*}{ SEM $^{1}$} & \multirow{2}{*}{ P-value } \\
\hline & $\mathbf{0}$ & 4 & 8 & & \\
\hline \multicolumn{6}{|l|}{ Growth performance ${ }^{2}$} \\
\hline \multicolumn{6}{|l|}{ Feed intake $(\mathrm{kg})$} \\
\hline Weeks 1 - 3 & $1.15 \pm 0.06$ & $1.13 \pm 0.05$ & $1.16 \pm 0.04$ & 0.025 & 0.065 \\
\hline Weeks $4-6$ & $3.32^{b} \pm 0.06$ & $3.32^{\mathrm{b}} \pm 0.12$ & $3.54^{\mathrm{a}} \pm 0.08$ & 0.196 & $<0.001$ \\
\hline \multicolumn{6}{|l|}{ Bodyweight $(\mathrm{BW}, \mathrm{kg})$} \\
\hline Initial & $0.05 \pm 0.001$ & $0.04 \pm 0.002$ & $0.04 \pm 0.003$ & 0.002 & 0.829 \\
\hline Final & $2.32 \pm 0.09$ & $2.32 \pm 0.95$ & $2.45 \pm 0.11$ & 0.085 & 0.109 \\
\hline Gain & $2.28^{\mathrm{b}} \pm 0.09$ & $2.28^{\mathrm{b}} \pm 0.04$ & $2.41^{\mathrm{a}} \pm 0.09$ & 0.072 & 0.043 \\
\hline Average daily gains (g) & $44.8^{b} \pm 0.3$ & $44.3^{b} \pm 1.0$ & $47.9^{\mathrm{a}} \pm 0.6$ & 2.14 & 0.034 \\
\hline Feed conversion ratio ${ }^{3}$ & $1.95 \pm 0.10$ & $1.95 \pm 0.08$ & $1.91 \pm 0.05$ & 0.243 & 0.436 \\
\hline \multicolumn{6}{|l|}{ Carcass properties ${ }^{4}$} \\
\hline Carcass weight & $1.68^{b} \pm 0.21$ & $1.66^{\mathrm{b}} \pm 0.16$ & $1.83^{\mathrm{a}} \pm 0.14$ & 0.581 & 0.032 \\
\hline Dressing percentage & $74.7 \pm 5.5$ & $74.8 \pm 12.6$ & $72.9 \pm 2.7$ & 6.71 & 0.197 \\
\hline \multicolumn{6}{|c|}{ Retail cuts ( $\%$ of chilled carcass) } \\
\hline Breasts $^{5}$ & $29.1^{\mathrm{b}} \pm 2.8$ & $30.9^{\mathrm{a}} \pm 3.8$ & $31.3^{\mathrm{a}} \pm 2.5$ & 3.08 & 0.005 \\
\hline Tenderloins $^{6}$ & $5.05^{\mathrm{c}} \pm 0.6$ & $5.48^{\mathrm{a}} \pm 0.7$ & $5.21^{\mathrm{b}} \pm 0.6$ & 0.60 & 0.008 \\
\hline Thighs & $18.5^{\mathrm{b}} \pm 1.3$ & $18.0^{\mathrm{b}} \pm 2.4$ & $19.5^{\mathrm{a}} \pm 1.9$ & 1.65 & 0.002 \\
\hline Drumsticks & $14.7 \pm 1.2$ & $14.5 \pm 1.9$ & $14.8 \pm 1.2$ & 1.90 & 0.082 \\
\hline Sum of all four cuts & $67.3^{b} \pm 2.7$ & $68.9^{b} \pm 1.9$ & $70.8^{\mathrm{a}} \pm 3.0$ & 2.22 & $<0.001$ \\
\hline Abdominal fat $(\%$ of $\mathrm{BW})$ & $2.77^{\mathrm{a}} \pm 0.63$ & $2.17^{\mathrm{b}} \pm 0.65$ & $2.05^{\mathrm{c}} \pm 0.72$ & 0.652 & $<0.001$ \\
\hline \multicolumn{6}{|c|}{ a-c Means in the same row with different superscripts differ significantly $(\mathrm{p}<0.05)$. } \\
\hline \multicolumn{6}{|c|}{1 SEM: Standard error of the mean. } \\
\hline \multicolumn{6}{|c|}{${ }^{2} \mathrm{n}=4$ pens with ten birds each per diet. } \\
\hline \multicolumn{6}{|c|}{3 Across weeks $1-6}$. \\
\hline \multicolumn{6}{|c|}{${ }^{4} \mathrm{n}=40$ birds per diet. } \\
\hline \multicolumn{6}{|c|}{5 The outer part of $M$. pectoralis major. } \\
\hline${ }^{6}$ The inner part of $M . p e c$ & major. & & & & \\
\hline
\end{tabular}

\section{Discussion}

\section{Perilla meal composition}

The batch of used perilla meal contained almost as much crude protein (36 to $40 \%$ ) as reported in previous research [12]. The lipids (12\%) of the batch used, from residual oil remaining after extraction, were a rich source of $\alpha$-linoleic acid $[9,12]$. It would be very interesting to investigate if the $\alpha$-linoleic acid would be able to accumulate in broiler meat. We found no further reports on nutrient compositions in studies testing perilla meal as a feed additive. 
http://wjst.wu.ac.th

\section{Effects on intake, performance, digestibility, and metabolizability}

Fiber has generally a low digestibility in poultry. In response to the elevated fiber contents within the dietary treatments, birds attempt to increase intake to ensure sufficient energy supply. Previous researchers reported an increase in intake by 3 to $9 \%$ in turkeys along with dietary fiber content [18]. However, a large increase in fiber content enhances a quick gut fill, and the associated physical limitations terminate further intake, even though satiety is not reached. In the present study, the increases in fiber content (by 1.2 and $2.4 \%$ within the 4 and $8 \%$ perilla meal inclusions in the finisher phase) appear to have been small enough to be compensated by an increased intake (found within the $8 \%$ inclusion in both experiments). These slight increases in intake with perilla meal seem to have enhanced growth performance within the higher inclusion levels of perilla meal in experiment 2, and thus led to an unchanged feed conversion ratio. A previous experiment with Korean native chickens [9] did not reveal similar effects of $10 \%$ perilla meal inclusion (likely rich in oil); however, this type of chicken has only a small growth potential compared to that of broilers. A perilla inclusion of $10 \%$ in pig meal feed led to a similar decline in growth performance [12]. Higher levels (40\%) of perilla meal as a soybean substitute also produced poor growth performances [10]. Moreover, decreasing ADG in the last week (week 5 to 6) may be due to the effect of heat stress because, during this time, it had the highest temperature $\left(43^{\circ} \mathrm{C}\right)$. A previous study reported that temperatures higher than $32{ }^{\circ} \mathrm{C}$ may induce hyperthermia and dehydration, leading to lower feed consumption and delayed growth [19]. A decline in fiber digestibility coincided with higher proportions of fiber, especially in the insoluble fiber of perilla meals than in the feeds typically replaced by perilla meal. Moderate amounts of insoluble fiber have been reported to increase the efficiency of the gizzard. Acting as a type of pacemaker, the gizzard is able to stimulate other digestive organs and cause an increase in the secretion of gastric enzymes [20]. Therefore, the consequence of more insoluble fiber could result in an increase in the digestibility of other dietary nutrients. This was found by feeding broilers rice hulls, which also contain high proportions of insoluble fiber [21]. However, in the present experiment, only the apparent metabolizability of $\mathrm{N}$, and not that of energy, increased. Additional insoluble fiber may also have negative effects, such as the interference with fat digestion by binding bile acids [22], resulting in a decreased fat digestibility [23], an observation also made in the present study. Similarly, the supplementation of up to $25 \%$ high-fiber sunflower meal to broilers resulted in a decreased fat digestibility [23]. In the present study, however, perilla meal inclusion also replaced other dietary fats, which led to an increase in ether extract content. This suggests that there may be inherent differences in the digestibility of different fat sources, especially when attached to the seeds' fibrous hulls' residues, which may also have been responsible for the observed decline in fat digestibility. Likewise, the changes in dietary fat supply may affect fiber digestibility [22]. However, contrary to our results, the inclusion of $10 \%$ perilla in rabbits' diet increased the apparent ether extract digestibility in the study of Peiretti et al. [10]; however, these researchers used the full-fat seeds.

\section{Effects on carcass quality}

In an effort to increase the proportions of the retail cuts, specifically, breast meat, which is the largest and most profitable, this experiment demonstrated the value of protein derived from the inclusion of perilla meal compared to that of soybean meal protein. Protein levels were maintained by adjusting the dietary protein contents to the levels recommended by Thailand's Department of Livestock Development [13]. The major constituent within these valuable cuts are muscles, and, therefore, the protein levels require the limiting amino acids like lysine to be absorbed in amounts necessary to produce muscle biomass. Accordingly, the quality of protein and its digestibility are critical for meat formation in growing poultry [22]. Perilla seed proteins seem to have a relatively high value, yet they are still limited in lysine [8] and digestibility [10] when compared to soybean meal, when the latter is provided with an inactivated trypsin inhibitor. However, a high protein value of perilla meal, replacing soybean meal in an isonitrogenous manner, was further confirmed in the present study by the substantial and linear increase in apparent $\mathrm{N}$ metabolizability with increasing proportions. While the positive effects of perilla meal on breast proportion of $\mathrm{BW}$ in Korean native chickens were not evident, there was also an enhancement of 
http://wjst.wu.ac.th

thigh muscle proportions [9]. A further study showed a decrease in breast yield proportions and protein digestibility in broilers fed a diet with $20 \%$ flaxseed compared to the control [25].

The abdominal fat proportion is also indicative of the feeding value of a diet, in which a decrease was found in the present study with increasing perilla meal proportions. These findings in the present study may be due to a lower dietary ME content or a metabolic situation where the ME was preferably utilized for synthesizing body protein, which is energetically demanding. As growth performance was not impaired, and the diet's measured dietary ME content was unaffected, the second explanation seems to be more plausible to perilla meal. However, a third possibility arises from changes in the fatty acid profile of the diet. Unsaturated fatty acids from sunflower oil were found to lower abdominal fat accumulation in broilers, compared to a diet characterized by saturated fatty acids [26]. Unsaturated fatty acids are more likely spent for metabolic and functional purposes, undergo $\beta$-oxidation, and are less likely used for depot fat synthesis [27]. The n-6:n-3 fatty acid ratio of the present diets clearly declined with increased additions of perilla meal. The amount of extra palm oil was not enough to increase the proportion of saturated fatty acids in the perilla meal diets in a detrimental way. This suggests that the meat from perilla-meal-fed broilers would have exhibited a very favorable fatty acid profile as well.

\section{Conclusions}

The present results demonstrate that perilla meal has a relatively high value as a protein source and allows a partial replacement of soybean meal in broilers' diets, and provides a higher carcass quality. It could be that perilla meal might successfully replace even higher proportions of soybean meal in broiler diets, as the $8 \%$ perilla meal inclusion proved to be superior to the $4 \%$ inclusion. However, other studies have indicated that an upper limit might exist as well. The present study also gave some insight into other nutrients present in perilla meal. There appear to be some effects in the fiber, likely originating from the perilla seeds' hulls. Particular value was determined by the richness of n-3 fatty acids in the perilla seed oil. However, we estimate that given more efficient oil extraction techniques, the oil remaining in the perilla meal would largely decline; an aspect must be carefully monitored.

\section{Acknowledgments}

The authors wish to gratefully acknowledge the financial support through participation in the Project $\mathrm{PhD} \mathrm{50} 0^{\text {th }}$ Anniversary Chiang Mai University and Functional Food for Well-Being, Chiang Mai University, Chiang Mai, Thailand. In addition, we extend our thanks to the Faculty of Animal Science and Technology, Maejo University, Chiang Mai, Thailand for the animals, facilities, and materials that supported our research.

\section{References}

[1] G Moreno, H Borba, G de Araujo, G Santos, R Souza and NO Boaventura. Rendimentos e cortes comerciais da carcaça de cordeiros Santa Inês alimentados com níveis de feno de erva-sal e concentrado. Rev. Bras. Saúde Prod. Anim. 2010; 15,192-205.

[2] S Hixson and C Parrish. Substitution of fish oil with camelina oil and inclusion of camelina meal in diets fed to Atlantic cod (Gadus morhua) and their effects on growth, tissue lipid classes, and fatty acids. J. Anim. Sci. 2014; 92, 1055-67.

[3] N Muangkeow and C Chinajariyawong. Diets containing fermented palm kernel meal with Aspergillus wentii TISTR 3075 on growth performance and nutrient digestibility of broiler chickens. Walailak J. Sci. \& Tech. 2013; 10, 131-47.

[4] S Oita, T Kimura, Y Shibuya, N Nihei and K Tanahashi. Extraction and digestibility of Perilla frutescens seed protein. Jpn. Agric. Res. Quart. 2008; 42, 211-4.

[5] K Deng, T Ma, Z Wang, W TanTai, H Nie, Y Guo, F Wang and X Fan. Effects of perilla frutescens seed supplemented to diet on fatty acid composition and lipogenic gene expression in muscle and liver of Hu lambs. Livest. Sci. 2018; 211, 21-9. 
http://wjst.wu.ac.th

[6] M Asif. Health effects of omega-3, 6, 9 fatty acids: Perilla frutescens is a good example of plant oils. Oriental Pharm. Exp. Med. 2011; 11, 51-9.

[7] P Zhang, C Tang, Z Ding, H Huang and Y Sun. Effects of simultaneous supplementation of laying hens with $\alpha$-linolenic acid and eicosapentaenoic acid/docosahexaenoic acid resources on egg quality and n-3 fatty acid profile. Asian-Australas. J. Anim. Sci. 2017; 30, 973-8.

[8] N Montha, W Yothinsirikul, K Tippaya, K Chompupan, C Lambertz and S Jaturasitha. Perilla mint (Perilla frutescens): An alternative animal feed to enhance omega-3 fatty acids in meat and eggs as functional food. J. Agric. Fac. Agric. Chiang Mai Univ. 2017; 33, 463-73.

[9] ST Oh, HK Jhun, JM Park, JM Kim, CW Kang and BK An. Effects of dietary sources containing $\omega-$ 3 fatty acids on the fatty acid composition of meats in Korean native chickens (in Korean). Korean J. Food Sci. Anim. Resource Res. 2012; 32, 476-82.

[10] HK Moon, JW Kim, KN Heo, YH Kim, SW Kim, CH Kwon, IS Shin and K Han. Growth performance and amino acid digestibilities affected by various plant protein sources in growingfinishing pigs. Asian-Austral J. Anim. Sci. 1994; 7, 537-46.

[11] PG Peiretti, F Gai, G Meineri, I Zoccarato and L Gasco. Apparent digestibility of compound diets with increasing levels of perilla (Perilla frutescens L.) seeds in rabbits. Ital. J. Anim. Sci. 2010; 9 , 425-8.

[12] M Yamada, A Soeta, S Sekiguti, J Aminaka, K Yamada and K Mutou. Effects of perilla meal feeding on the growth, carcass characteristics, and fatty acid composition of fat tissue and muscle in fattening pigs (in Japanese). Jpn. J. Swine Sci. 2005; 42, 45-53.

[13] Department of Livestock Development. Formula diet of economic animals. Bangkok, Thailand, 2004, p. 1-2.

[14] NB Song, JH Lee and KB Song. Preparation of perilla seed meal protein composite films containing various essential oils and their application in sausage packaging. J. Korean Soc. Appl. Biol. Chem. 2015; 58, 83-90.

[15] Office International des Epizooties (OIE) Animal welfare for a better world, Available at: https://www.oie.int/en/animal-welfare/animal-welfare-at-a-glance, accessed January 2020.

[16] AOAC (Association of Official Agricultural Chemists). Official methods of analysis. $18^{\text {th }}$ ed. Press, Washington DC, 2005, p. 1-73.

[17] N Nikolova and Z Pavlovski. Major carcass parts of broiler chicken from different genotype, sex, age, and nutrition system. Biotech. Anim. Husbandry 2009; 25, 1045-54.

[18] M Adibmoradi, B Navidshad and MJF Jahromi. The effect of moderate levels of finely ground insoluble fibre on small intestine morphology, nutrient digestibility and performance of broiler chickens. Ital. J. Anim. Sci. 2016; 15, 310-7.

[19] W Aengwanich. Effects of high environmental temperature on the body temperature of Thai indigenous, Thai indigenous crossbred and broiler chickens. Asian J. Poult. Sci. 2008; 2, 48-52.

[20] A Sadeghi, M Toghyani and AJ Gheisari. Effect of various fiber types and choice feeding of fiber on performance, gut development, humoral immunity, and fiber preference in broiler chicks. Poultry Sci. 2015; 94, 2734-43.

[21] M Adibmoradi, B Navidshad and MF Jahromi. The effect of moderate levels of finely ground insoluble fibre on small intestine morphology, nutrient digestibility and performance of broiler chickens. Ital. J. Anim. Sci. 2016; 15, 310-7.

[22] S Adams, CT Sello, GX Qin, D Che and R Han. Does dietary fiber affect the levels of nutritional components after feed formulation? Fibers 2018; 6, 29-45.

[23] M Alagawany, MR Farag, ME El-Hack and K Dhama. The practical application of sunflower meal in poultry nutrition. Anim. Vet. Sci. 2015; 3, 634-48.

[24] HS Cemin, SL Vieira, C Stefanello, M Kipper, L Kindlein and A Helmbrecht. Digestible lysine requirements of male broilers from 1 to 42 days of age reassessed. PloS One 2017; 12, 1-13.

[25] MB Moghadam, M Rezaei, M Behgar and H Kermanshahi. Effects of irradiated flaxseed on performance, carcass characteristics, blood parameters, and nutrient digestibility in broiler chickens. Poult. Sci. 2017; 2, 153-63. 
http://wjst.wu.ac.th

[26] J Carmona, C Lopez-Bote, A Daza and A Rey. Fat accumulation, fatty acids and melting point changes in broiler chick abdominal fat as affected by time of dietary fat feeding and slaughter age. Brit. Poult. Sci. 2019; 60, 219-28.

[27] S Omidi, A Mohit and N G Hossein-Zadeh. Effect of dietary fat level and source on performance and immune system response of turkeys. Acta Sci. Anim. Sci. 2020; 42, e46775-e46782. 